Sumadi $\cdot$ P. Suryatmana $\cdot$ D. Sobardini

\title{
Pengaruh aplikasi pelapisan benih terhadap viabilitas benih terdeteriorasi serta pertumbuhan tanaman kedelai
}

\section{The effect of seed coating application on deteriorated seed viability and soybean growth dynamics}

Diterima : 15 Juli 2016/Disetujui : 10 Agustus 2016 / Dipublikasikan : 30 Agustus 2016

CDepartment of Crop Science, Padjadjaran University

\begin{abstract}
Plant growth dynamics was affected by seed quality. The objectives of this study was to examine deteriorated seeds response to the application of various coatings, either insecticides or biological coatings in the form of suspension of the microorganism that is reflected by an increase in crop growth. The experiment was split plot design with two factors, namely the level of seed deterioration (D) consisting of good quality seed (GC $=84 \%$ ) and deteriorated seed $(\mathrm{GC}=75 \%)$. Seed coatings used consisted of Thiametoxam, Rhizobium sp, sp Azotobakter, mix of Azotobakter and Rhizobium sp, and Trichoderma sp. Experimental results showed that there was no interaction effect between the level of deterioration of the seed to the type of seed coatings on all parameters were observed. Quality seed growth respons differently to a given type of seed coating, but the effect is not significantly difference. Applications of an insecticide or biological seed coating are not able to improve deteriorated seeds, but affected of Chlorophyll content index, Relative Crop Growt, Nett Assimilation Rate and Shoot Root Ratio. In general, Rhizobium sp and Azotobacter sp can increase the number of effective nodules.
\end{abstract}

Keywords: Deteriorated seed - Seed coatings . Thiametoxam - Azotobakter sp · Rhizobium sp . Trichoderma sp · Viability

Sari Kualitas benih akan mempengaruhi dinamika pertumbuhan tanaman. Tujuan penelitian ini adalah untuk mengkaji respons benih terdeteriorasi terhadap aplikasi berbagai pelapis benih, baik berupa insektisida maupun

\footnotetext{
Dikomunikasikan oleh Agus Wahyudin

Sumadi $^{1} \cdot$ P. Suryatmana ${ }^{1} \cdot$ D. Sobardini ${ }^{1}$

${ }^{1}$ Staf pengajar Program Studi Agroteknologi Fakultas

Pertanian Unpad

Korespondensi: sumadi@unpad.ac.id
}

pelapis hayati berupa suspensi mikroorganisma yang dicerminkan dengan peningkatan laju tumbuh tanaman. Penelitian merupakan percobaan petak terbagi dua faktor, yaitu tingkat deteriorasi (D) yang terdiri dari benih berkualitas baik (DB $=84 \%$ ) dan benih terdeteriorasi $(\mathrm{DB}=75 \%)$. Pelapis benih yang digunakan terdiri dari Thiametoxam, Rhizobium sp , Azotobakter sp , campuran Azotobakter sp + Rhizobium sp, dan Trichoderma sp. Hasil Percobaan menunjukkan bahwa tidak ada pengaruh interaksi antara tingkat deteriorasi benih dengan jenis pelapis benih terhadap semua parameter yang diamati. Kualitas benih memberi respons pertumbuhan yang berbeda terhadap jenis pelapis benih yang diberikan. Aplikasi pelapis benih berupa insektisida maupun inokulan mikroorganisme tidak mampu meningkatkan vigor benih yang sudah terdeteriorasi, tetapi berpengaruh terhadap jumlah nodula efektif, perkembangan klorofil, Laju Tumbuh Relatif, Laju Asimilasi Bersih , dan Nisbah Pupus Akar. Secara umum pemberian Rhizobium sp dan Azotobacter sp dapat meningkatkan jumlah nodula efektif, tetapi tidak secara nyata mempengaruhi pertumbuhan tanaman.

Kata kunci : Pelapis benih - Thiametoxam . Azotobakter sp - Rhizobium sp . Trichoderma sp . Viabilitas · Vigor benih

\section{Pendahuluan}

Kedelai (Glycine $\max$ (L.) Merr) merupakan komoditas utama pangan penting setelah padi dan jagung. Kedelai merupakan salah satu sumber protein dan lemak nabati penting sehingga merupakan bahan baku potensial untuk produk olahan, baik skala kecil maupun untuk keperluan industri pangan. 
Kebutuhan akan kedelai terus meningkat sejalan pertambahan penduduk dan peningkatan pemahaman akan nilai gizi yang dikandung biji kedelai, namun produksi kedelai di Indonesia terus mengalami penurunan. Penurunan produksi tidak lepas dari berkurangnya areal pertanaman kedelai di beberapa wilayah serta penggunaan benih yang bermutu rendah. Selain itu rendahnya produksi kedelai dan turunnya mutu biji kedelai adalah adanya serangan hama dan penyakit yang menyerang sejak saat awal fase vegetatif sampai menjelang panen (Adisarwanto dan Wudianto, 1999; Marwoto dkk., 2008 ; Sumadi.,dkk 2012).

Pelapisan benih dengan insektisida atau seed coating dapat melindungi benih dari hama dan penyakit yang menyerang benih pada fase vegetatif awal, sehingga pertumbuhan tanaman tidak terganggu dan dapat bertahan sampai pada fase akhir (Cox et al., 2007; Syngenta, 2009). Beberapa penelitian menunjukkan thiametoksam, imidakloprid atupun fipronil sama-sama memberikan pengaruh baik bagi pertumbuhan dan pengendalian hama pada fase awal pertumbuhan dibandingkan dengan kontrol (Wilde et al., 2004 )

Selain penggunaan pestisida sintetik, pelapisan benih dapat menggunakan agen hayati maupun bahan organik lainnya, baik yang berupa mikroba anti patogen maupun mikroba yang mampu meningkatkan kesuburan media tanam. Pelapisan benih dengan agen hayati dikenal dengan biological seed treatment (Copeland dan McDonald, 2004) atau perlakuan benih secara hayati (Agustiansyah, dkk., 2010 : Ilyas, 2012), salah satunya adalah dengan Trichoderma. Trichoderma dapat juga berperan sebagai antipatogen tular tanah. Spesies Trichoderma adalah cendawan yang hidup bebas, umum ditemui pada ekosistem tanah dan akar. Cendawan ini telah dipelajari secara ekstensif dalam kemampuannya menghasilkan antibiotik, memarasitisasi cendawan lain, dan mikroorganisme penyebab penyakit pada tanaman (Harman et al., 2004). Beberapa strain Trichoderma memberikan pengaruh penting dalam perkembangan dan produktivitas tanaman (Harman, 2006).

Pelapisan benih kedelai dengan agen hayati yang sudah sering dilakukan petani adalah pemberian inokulan rhizobium. Baik berupa biakan murni maupun tanah bekas pertanaman kedelai, sehingga tanaman akan menghasilkan biji lebih banyak (Adisarwanto dan Wudianto, 1999). Selain Rhizobium spp, dapat juga menggunakan bakteri penambat $\mathrm{N}$ lain yaitu Azotobacter spp. Azotobacter spp memiliki kelebihan lain, yaitu mampu meningkatkan kemampuan akar menyerap unsur hara (Milic et al., 2002).

Pemberian Rhizobium spp dan Azotobacter spp secara bersama-sama pada Vicia faba hasilnya lebih baik dibandingkan yang diberikan secara terpisah (Rodelas et al., 1999). Azotobacter tidak saja memfiksasi $\mathrm{N}_{2}$ dari udara tetapi juga memperbaiki perkembangan akar. Selain pada jenis Leguminosae, Azotobacter juga banyak terdapat pada jenis rumput, khususnya Paspalum notatum (Doberreiner dan Day, 1976 dalam Fitter dan Hay, 1987). Kemampuan Azotobacter sp memperbaiki perkembangan akar karena menghasilkan fitohormon golongan auxin dan sitokinin (Suryatmana, dkk, 2008).

Keefektifan setiap jenis pelapis benih sebagaimana terukur pada viabilitas, vigor, pertumbuhan bergantung pada kualitas benih yang digunakan.

\section{Bahan dan Metode}

Penelitian merupakan percobaan pot (bobot kering tanah $10 \mathrm{~kg}$ ) yang dilaksanakan di lahan kebun percobaan Fakultas Pertanian Universitas Padjadjaran, Jatinangor, Jawa Barat, dengan ketinggian $\pm 750 \mathrm{~m}$ di atas permukaan laut. Pelaksanaan dimulai akhir Maret - akhir Juli 2014. Pengujian kualitas benih dilaksanakan di Laboratorium Teknologi Benih Departemen Budidaya Pertanian Faperta Unpad, Suspensi Rhizobium sp dan Azotobacter sp diperoleh dari Laboratorium Biologi Tanah, Departemen Ilmu Tanah dan Sumber Daya Lahan Faperta Unpad, Trichoderma sp dan Thiametoxam merupakan produk yang siap pakai diperoleh dari kios Saprotan di Lembang, Benih kedelai kultivar Anjasmoro yang baru dipanen (DB $=84 \%$, IV = 7,48) diperoleh dari UPTD Balai Pengembangan Benih Palawija, Plumbon, Kab Cirebon dan Benih terdeteriorasi (DB $=74 \%$, IV = 6,65) diperoleh dari koleksi laboratorium Teknologi Benih Faperta Unpad. Analisis tanah dan populasi mikroba pada media tanam dilakukan di Laboratorium Biologi Tanah Faperta Unpad dan Lembaga Penelitian Tanah Kementrian Pertanian di Bogor, Uji Kan-dungan protein benih dilakukan di Laboratorium Agrokimia UPTD Dinas Pertanian Tanaman Pangan Jawa Barat, di Lembang.

Percobaan dirancang dalam Rancangan Petak Terbagi dua faktor. Sebagai petak utama 
tingkat deteriorasi benih (D) terdiri dua taraf, yaitu $\mathrm{d}_{1}=$ daya berkecambah $84 \%$ dan $\mathrm{d}_{2}=$ daya berkecambah $74 \%$. Sebagai anak petak adalah jenis pelapis benih $(C)$ yang terdiri dari enam taraf, yaitu $\mathbf{c}_{0}=$ tanpa pelapisan benih, $\mathrm{c}_{1}=$ thiametoxam, $\mathrm{c}_{2}=$ Rhizobium $\mathrm{sp}, \mathrm{c}_{3}=$ Azotobakter sp, $\mathbf{c}_{4}=$ Azotobakter $s p+$ Rhizobium sp. dan $\mathrm{c}_{5}=$ Trichoderma sp.

Semua perlakuan diulang tiga kali. Setiap unit percobaan terdiri dari enam buah pot percobaan, sehingga seluruhnya terdapat $2 \times 6 \times$ $6 \times 3=216$ pot percobaan. Kepadatan Inokulan Azotobacter sp, Rhizobiumsp dalam carrier pelapis benih yang digunakan adalah $10^{9} \mathrm{CFU} / \mathrm{g}$ carrier pelapis, sedangkan kepadatan Trichoderma sp dalam carrier pelapis benih adalah $10^{7} \mathrm{CFU} / \mathrm{g}$ carrier pelapis. Pemberian pelapisan benih dengan cara mencampur setiap pelapis benih dengan benih dengan menggunakan kantong plastik. Penanaman (tiga benih per pot) sekaligus memberi pupuk $\mathrm{N}$ (setengah dosis) $\mathrm{P}$ dan $\mathrm{K}$ pada saat tanam dosis anjuran untuk tanah inceptisol. Pemeliharaan : penjarangan tanaman (menyisakan satu tanaman per pot) dilakukan pada 2 mst (minggu setelah tanam), penyiraman, pengendalian hama dan penyakit. Destruktif tanaman dilakukan tiap dua minggu mulai 2 mst sampai $10 \mathrm{mst}$, untuk memperoleh bobot kering tanaman (bobot kering akar, batang dan daun). Analisis data menggunakan program Toolpack dari Microsoft Excel.

\section{Hasil dan Pembahasan}

Suhu dan kelembaban udara rata-rata sampai 9 minggu setelah tanam (mst) masingmasing sbb : pagi hari $18,6{ }^{\circ} \mathrm{C}-22.0^{\circ} \mathrm{C}$, sedangkan siang hari rata-rata mencapai 30.90 C. Kelembaban pada siang hari rata-rata 60- 64 $\%$. Pada awal tanam sampai 4 mst curah hujan masih cukup tinggi, selanjutnya mulai $6 \mathrm{mst}$ curah hujan sudah mulai berkurang. Walaupun demikian sampai 9 mst masih ada hujan gerimis. Daya berkecambah benih sebelum tanam masing-masing $84 \%\left(\mathrm{~d}_{1}\right)$ dan $75 \%\left(\mathrm{~d}_{2}\right)$. Hasil analisis media tanam sebelum percobaan hanya bakteri Azotobacter sp yang ditemukan, yaitu sebanyak $3,34 \times 10^{8} \mathrm{cfu} / \mathrm{g}$. Hal ini berarti keberadaan Azotobacter sp pada media percobaan sudah cukup banyak. Hal yang berbeda dengan Rhizobium sp dan Trichoderma sp yang tidak terdeteksi.

Tanah tergolong agak masam (5.88), kandungan unsur hara $\mathrm{N}, \mathrm{P}$ tersedia dan $\mathrm{K}$ masing-masing dikategorikan sedang $(0.27 \%)$, rendah $(6.20 \mathrm{mg} / 100 \mathrm{~g})$ dan rendah (16.61 $\mathrm{mg} / 100 \mathrm{~g})$, tekstur tanah tergolong liat (Laboratorium Kesuburan Tanah dan Nutrisi Tanaman Departemen ITSL Faperta Unpad, 2014). Kondisi demikian masih cukup baik untuk pertanaman kedelai. Organisme pengganggu yang dijumpai saat tanaman umur $2 \mathrm{mst}$ sampai 9 mst adalah ulat penggerek daun, kepik hijau, belalang. Tingkat serangan sangat rendah, sehingga tidak mengganggu hasil percobaan secara signifikan. Setiap dua minggu dilakukan pengendalian dengan pestisida.

Hasil analisis statitistik menunjukkan bahwa tidak ada pengaruh interaksi terhadap semua parameter utama yang diamati. Vigor daya tumbuh benih, bobot kering kecambah dan jumlah nodula efektif disajikan pada Tabel 1.

Tabel 1. Daya Tumbuh Benih, Bobot Kering Kecambah, Jumlah Nodula Efektif.

\begin{tabular}{llll}
\hline \hline Perlakuan & $\begin{array}{l}\text { Daya } \\
\text { Tumbuh } \\
(\%)\end{array}$ & $\begin{array}{l}\text { Bobot } \\
\text { Kering } \\
\text { Kecambah } \\
(\mathrm{g})\end{array}$ & $\begin{array}{l}\text { Jumlah } \\
\text { Nodula } \\
\text { Efektif }\end{array}$ \\
\hline $\begin{array}{l}\text { Deteriorasi (D) } \\
\mathrm{d}_{1}=\text { vigor baik }\end{array}$ & $66,67 \mathrm{a}$ & $0,56 \mathrm{a}$ & $12,44 \mathrm{a}$ \\
$\mathrm{d}_{2}=$ vigor rendah & $68,89 \mathrm{a}$ & $0,55 \mathrm{a}$ & $15,83 \mathrm{a}$ \\
Pelapis Benih (C) & & & \\
$\mathrm{c}_{0}=$ tanpa pelapis & $68,67 \mathrm{a}$ & $0,57 \mathrm{a}$ & $9,00 \mathrm{a}$ \\
benih & $69,33 \mathrm{a}$ & $0,53 \mathrm{a}$ & $11,00 \mathrm{a}$ \\
$\mathrm{c}_{1}=$ thiametoxam & $68,67 \mathrm{a}$ & $0,54 \mathrm{a}$ & $23,33 \mathrm{~b}$ \\
$\mathrm{c}_{2}=$ Rhizobium sp (R) & $74,00 \mathrm{a}$ & $0,53 \mathrm{a}$ & $17,67 \mathrm{ab}$ \\
$\mathrm{c}_{3}=$ Azotobacter sp (A) & $67,33 \mathrm{a}$ & $0,59 \mathrm{a}$ & $15,50 \mathrm{ab}$ \\
$\mathrm{c}_{4}=\mathrm{R}+$ A & $58,67 \mathrm{a}$ & $0,54 \mathrm{a}$ & $8,33 \mathrm{a}$ \\
$\mathrm{c}_{5}=$ Trichoderma sp & & & \\
\hline
\end{tabular}

Keterangan: Angka yang ditandai huruf yang sama pada kolom yang sama menunjukkan tidak berbeda nyata menurut uji jarak berganda Duncan pada taraf $5 \%$

Aplikasi berbagai jenis pelapis benih tidak mampu meningkatkan vigor benih terdeteriorasi. Vigor benih setelah diberi pelapisan benih tidak masuk kategori bervigor tinggi. Apabila dibandingkan dengan kualitas awal benih yang hanya bervigor sedang, perlakuan pelapisan benih dengan insektisida maupun secara hayati tidak berpengaruh negatip secara signifikan (Tabel 1). Tingkat vigor benih maupun pelapis benih masing-masing tidak berpengaruh nyata terhadap daya tumbuh kecambah maupun terhadap bobot kering kecambah.

Hal ini diduga bahwa pelapis benih tidak berperan langsung sebagai zat yang merangsang proses perkecambahan maupun memperbaiki 
vigor benih terdeteriorasi. Beberapa zat kimia yang mampu memperbaiki vigor benih antara lain asam giberelat, sitokinin dan $\mathrm{KNO}_{3}$ (Copeland dan McDonald, 2004). Pelapis benih berpengaruh terhadap jumlah bintil akar efektif, sedangkan kualitas benih tidak berpengaruh nyata terhadap pembentukan nodula efektif. Nodula efektif paling banyak terdapat pada tanaman yang benihnya diberi Rhizobium, tetapi tidak berbeda nyata dengan yang diaplikasi Azotobacter sp. Keduanya merupakan bakteri penambat $\mathrm{N}_{2}$ dari udara. Pembentukan nodula efektif yang lebih tinggi diharapkan berkorelasi positif dengan pertumbuhan tanaman selanjutnya.

Secara umum dinamika pertumbuhan tanaman kedelai asal benih terdeteriorasi yang diberi pelapis benih mempunyai pola yang sama. Pertumbuhan dan perkembangan adalah perubahan yang sejalan dengan waktu dan rangkaian kejadian organogenesis serta ontogony setiap organ berdasarkan pola tertentu suatu sel dan jaringan tanaman Harrison, 1971 dikutip Akyas, 1990; Saliburry dan Ross, 1992). Grafik perkembangan Kandungan Klorofil (KK), Laju Tumbuh Relatif (LTR), Laju Asimilasi Bersih (LAB) dan Nisbah Pupus Akar (NPA) akibat pemberian pelapis benih (c) pada setiap tingkat deteriorasi benih (D) disajikan pada Gambar 1,2,3 dan 4.
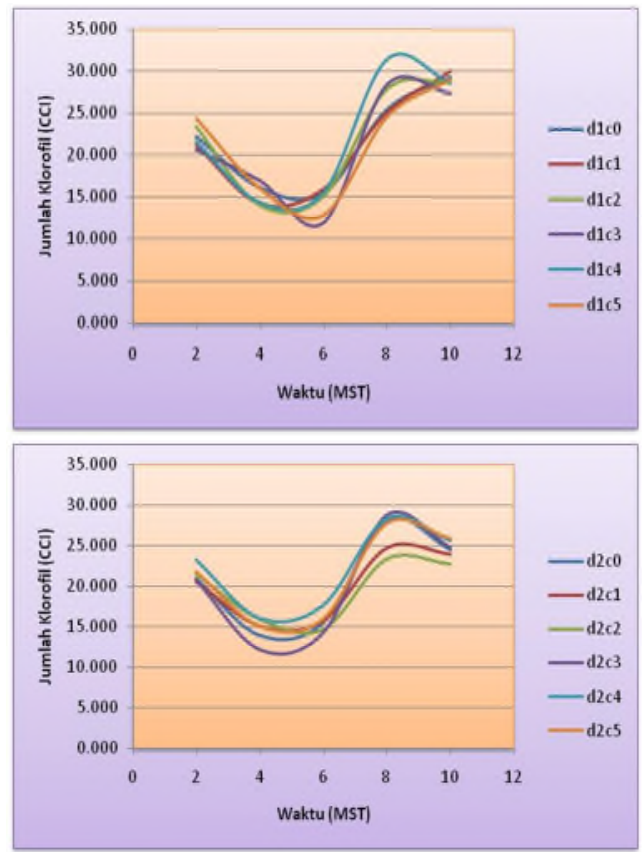

Gambar 1. Perkembangan Klorofil Dua Mingguan 2 MST -10 MST pada Tanaman Asal Benih Terdeteriorasi yang Diaplikasi Berbagai Pelapis Benih.
Perkembangan Kandungan Klorofil (KK) Daun Dua Mingguan. Berdasarkan pada matriks keberimpitan dan bersilangan faktor pelapis benih (C) pada setiap kualitas benih (D), menunjukkan pengaruh pelapis benih terhadap kandungan klorofil secara nyata hanya terdapat pada daun tanaman asal benih yang bervigor baik $\left(\mathrm{d}_{1}\right)$, sedangkan kandungan klorofil asal benih yang bervigor rendah $\left(\mathrm{d}_{2}\right)$ pengaruhnya tidak nyata.

Pemberian pelapis benih berupa campuran Rhizobium sp dan Azotobacter sp ( $\left.\mathrm{c}_{4}\right)$ kandungan klorofilnya berbeda nyata lebih baik dibandingkan dengan tanaman asal benih yang diaplikasi Trichoderma sp. Pelapis benih lainnya tidak memberikan pengaruh yang nyata dibandingkan dengan pelapis benih lainnya.

Perkembangan Laju Tumbuh Relatif (LTR) dua mingguan (g.g. hari ${ }^{-1}$ ). Dinamika pertumbuhan tanaman kedelai mulai 2 mst sampai 10 mst sebagaimana digambarkan pada kurva LTR secara umum merupakan kurva sigmoid. Pertumbuhan diawali fase logaritmic, dilanjutkan fase linier dan berakhir fase senesen. Berdasarkan pada uji keberimpitan dan bersilangan denga Uji Chow menunjukkan bahwa pelapis benih memberi pengaruh yang berbeda pada setiap tingkat vigor benih (D) (Gambar 2). Berdasarkan pada matriks keberimpitan dan bersilangan menunjukkan bahwa
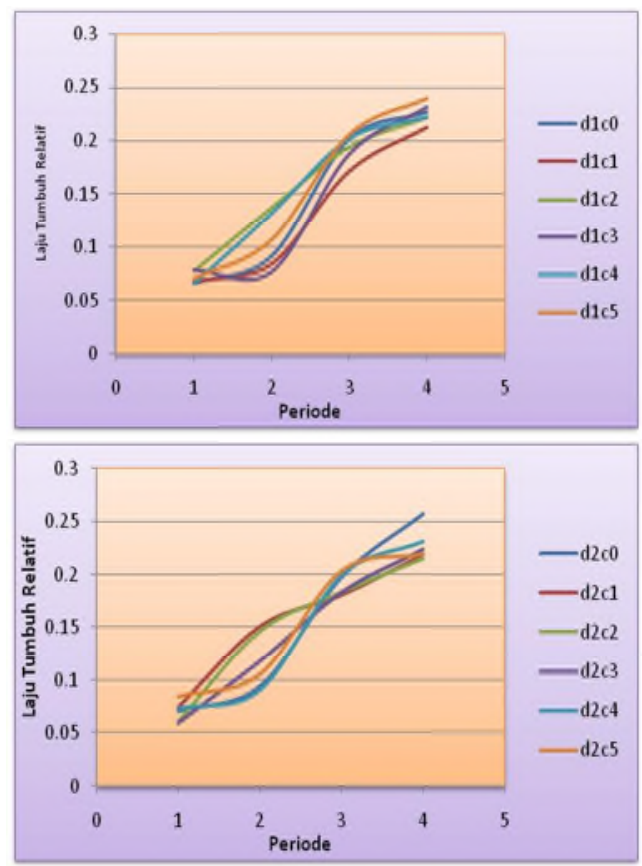

Gambar 2. Perkembangan Laju Tumbuh Relatif Dua Mingguan 2-10 MST Tanaman Asal Benih Terdeteriorasi yang Diaplikasi Berbagai Pelapis Benih. 
jenis pelapisan benih (C) pengaruhnya tidak konsisten pada setiap tingkat vigor benih (D). Pada tanaman asal benih bervigor baik $\left(\mathrm{d}_{1}\right)$ pelapisan benih dengan Rhizobium $s p$ berbeda nyata dengan yang tanpa pelapisan benih, thiametoxam, azotobakter dan campuran Rhizobium sp dan Azotobacter sp, sedangkan LTR tanaman asal benih yang dilapisi Trichoderma sp pengaruhnya tidak berbeda nyata dengan perlakuan pelapis benih lainnya.

Berbeda halnya dengan LTR tanaman asal benih yang bervigor rendah $\left(\mathrm{d}_{2}\right)$ pelapisan benih tidak berpengaruh nyata, tidak responsif terhadap aplikasi berbagai jenis pelapis benih.

Perkembangan Laju Asimilasi Bersih (LAB) Tanaman dua mingguan (g hari ${ }^{-1}$ ). Laju Asimilasi Bersih atau LAB merupakan perkembangan asimilat atau fotosintat bersih yang diakumulasikan dalam oragn-orang simpanan (sink). Dengan perkataan lain LAB merupakan selisih asimilat atau fotosintat total yang dihasilkan dalam proses fotosintesis yang telah diganakan untuk menyusun organ-organ baru dan proses respirasi. Perkembangan LAB dua mingguan antara tanaman kedelai yang berasal dari bervigor baik dan bervigor rendah yang diaplikasi berbagai pelapis benih disajikan pada Gambar 3. Berdasarkan pada hasil uji kesejaran dan keberimpitan sebagaimana ditampilkan pada matriks keberimpitan dan bersilangan, LAB semua tanaman menunjukkan perbedaan yang nyata pada setiap pemberian pelapis benih dan vigor benih.
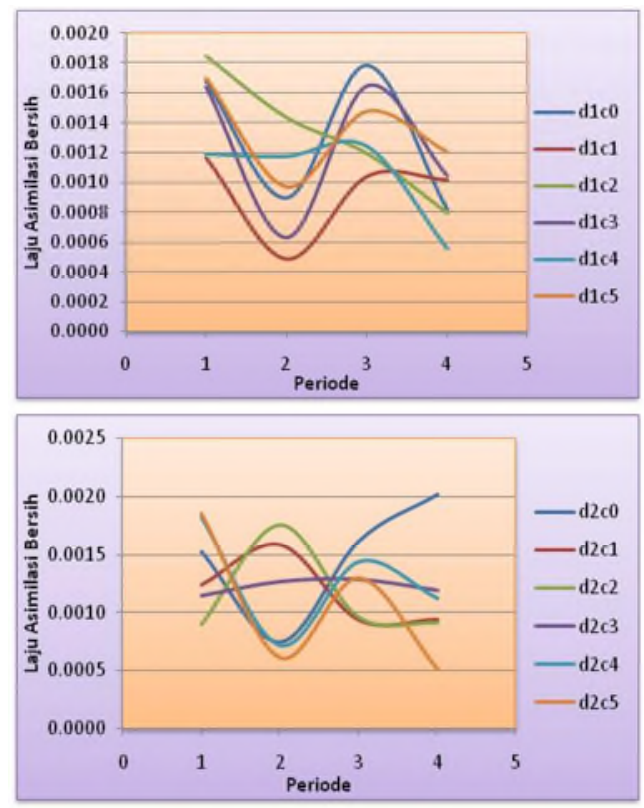

Gambar 3. Perkembangan Laju Asimilasi Bersih Dua Mingguan 2-10 MST Tanaman Kedelai Asal Benih Terdeteriorasi yang Diaplikasi Berbagai Pelapis Benih.
LAB tanaman asal benih yang tidak diberi pelapis benih menunjukkan kecenderungan lebih tinggi dibandingkan dengan yang diberi pelapis benih. Hal ini diduga, tingkat efisiensi pemanfaatan asimilat tanaman asal benih yang tidak diberi pelapis benih lebih baik, tetapi faktor lingkungan setelah 10 mst juga berpengaruh terhadap tumbuh selanjutnya. Hal ini dibuktikan dengan hasil biji yang lebih tinggi diperoleh oleh tanaman asal benih yang diberi pelapis hayati.

Perkembangan Laju Nisbah Pupus Akar (NPA) Tanaman dua mingguan (g hari ${ }^{-1}$ ). Perkembangan Laju Nisbah Pupus Akar atau NPA merupakan gambaran pola distribusi asimilat antara pupus (shoot) dengan akar (root). Sebagaimana laju tumbuh lainnya, perkembangan NPA juga lebih didominasi oleh pengaruh lingkungan tempat tumbuh tanaman. Dalam hal ini kondisi rhizospere untuk pertumbuhan dan perkembangan akar. Besar kecilnya dipengaruhi pola distribusi dan akumulasi asimilat, apakah lebih dominan untuk pertumbuhan bagian atas tanaman atau sebaliknya untuk pertumbuhan dan perkembangan bagian bawah tanaman. Pada kondisi media yang menyebabkan tanaman tercekam kekeringan, biasanya akar akan tumbuh lebih dominan dibandingkan dengan pertumbuhan pupus. Sebaliknya jika kondisi media kaya akan unsur hara terutama Nitrogen dan kandungan air cukup banyak, maka akar tidak berkem-

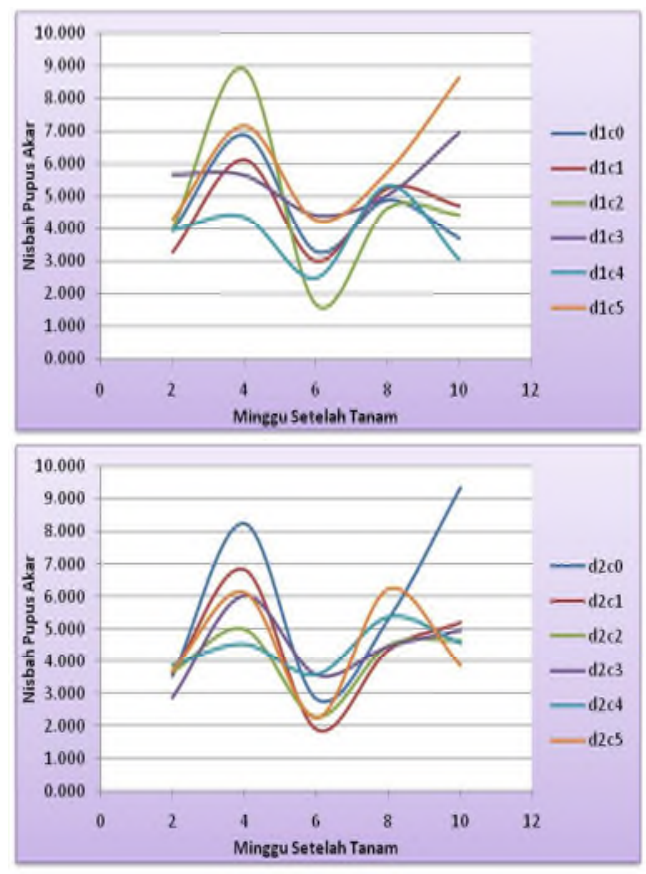

Gambar 4. Perkembangan Nisbah Pupus Akar 2 MST-10 MST Tanaman Asal Benih Terdeteriorasi yang Diaplikasi Pelapis Benih. 
bang dengan baik. Pada kondisi demikian nilai NPA akan cenderung lebih besar, karena bahan kering lebih banyak didistribusikan ke bagian pupus.

Berdasarkan pada hasil uji kesejajaran dan keberimpitan menunjukkan bahwa NPA tanaman asal benih terdeteriorasi yang diaplikasi berbagai pelapis benih menunjukkan pola yang sama. Hasil uji menunjukkan semuanya sejajar dan berimpit, artinya semuanya tidak ada perbedaan yang nyata antar pemberian pelapis benih. Tinggi rendahnya NPA tidak bisa dipisahkan dengan kandungan klorofil daun yang secara langsung mempengaruhi fotosintesis. Fotosintesis yang berjalan optimal akan mempengaruhi akumulasi asimilat pada organ reproduktif dan vegetatif.

Kandungan klorofil pada fase vegetatif masih rendah, selanjutnya mengalami peningkatan, tetapi sejalan bertambahnya umur mengalami penurunan. Hal ini sesuai dengan pola sintesis klorofil dan perombakan klorofil akibat adanya sintesis hormon sitokinin pada saat masih muda, diikuti meningkatnya etilen yang memacu aktivitas enzim klorofilase. Kandungan klorofil daun dan kondisi lingkungan berpengaruh terhadap laju asimilasi. NPA secara nyata dipengaruhi luas daun, bagi tanaman yang mempunyai luas daun yang besar akan menghasilkan asimilat yang lebih banyak. Permasalahannya apakah fotosintat yang terakumulasi ditranslokasikan pada sink reproduktif ataukah ke sink vegetatif. Aplikasi Rhizobium dan Azotobacter walaupun tidak signifikan mempengaruhi pertumbuhan, ada kecenderungan tumbuh vegetatifnya lebih baik dengan tanaman asal benih yang diaplikasi Thiametoxam dan Trichoderma sp.

\section{Keimpulan dan Saran}

Berdasarkan uraian tersebut dapat disimpulkan bahwa tidak ada pengaruh interaksi antara tingkat deteriorasi benih dan jenis pelapis benih terhadap semua parameter yang diamati. Aplikasi pelapis benih tidak mampu meningkatkan vigor benih yang sudah mengalami deteriorasi, tetapi berpengaruh terhadap jumlah nodula efektif, perkembangan klorofil, LTR, LAB , dan NPA.

Berdasarkan kesimpulan hasil penelitian maka dapat disarankan untuk mengkaji dosis kompos Trichoderma sp yang efektif dan efisien dalam peningkatan produktivitas tanaman kedelai asal benih terdeteriorasi yang ditanam langsung pada lahan kering. Selain itu untuk mengetahui vigor benih akibat pemberian Trichoderma perlu dilakukan pula pengkajian terhadap daya simpan benih yang dihasilkan.

\section{Ucapan Terimakasih}

Pada kesempatan ini saya ucapkan terimakasih kepada Direktorat Perguruan Tinggi yang telah mendanai penelitian ini serta pihak-pihak yang membantu memperlancar terselenggaranya selama pelaksanaan penelitian di lapangan.

\section{Daftar Pustaka}

Adisarwanto, T dan Wudianto, R.1999. Meningkatkan hasil panen Kedele di lahan Sawah, Lahan Kering dan Pasang Surut. Penebar Swadaya. Jakarta.

Agustiansyah, S. Ilyas, Sudarsono dan M. Machmud, 2010. Pengaruh Perlakuan Benih Secara Hayati pada Benih Padi Terinfeksi Xanthomonas oryzae terhadap Mutu benih dan Pertumbuhan Bibit. J. Agron. Indonesia 38 (3) : 185-191

Cox, W.J., Shields, E. and Cherney, J.H. 2008. Planting Date and Seed Treatment Effects on Soybean in the Northeastern United States.J.Agro 100:1662-1665

Cox, W.J., Shields, E. and Cherney, D.J.R., Cherney, J.H. 2007. Seed-Applied Insecticides Inconsistenly Affect Corn Forage in Continuous Corn. J.Agro 99: 1640-1644.

Copeland, L.O., and M.B McDonald. 2004. Principles of Seed Science and Technology. Burgess Publ. Co. Minneapolis, Minnesota.

Fitter, A. H., and R.K.M. Hay, 1987. Environmental Physiology of Plant. Academic Press. London.

Harman, G.E., 2006. Overview of mechanisms and uses of Trichoderma spp. Phytopathology 96, 190-194

Harman, G.E., Howell, C.R., Viterbo, A., Chet, I., Lorito, M., 2004. Trichoderma speciesopportunistic, avirulent plant symbionts. Nature reviews. Microbiology 2, 43-56

Ilyas, S. 2012. Ilmu dan Teknologi Benih. Teori dan hasil-hasil Penelitian. IPB Press. Bogor

Marwoto., Hardiningsih Sri dan Taufiq Abdulah. 2006. Hama, Penyakit, dan Masalah Hara pada Tanaman Kedelai. Pusat Peneltian dan 
Pengembangan Tanaman Pangan. Bogor.

Milic, V., N. Mrkovacki, M, Popovic, and D. Malencic. 2002. Nodule effenciency of three soybean genotypes inoculated by different methods. Rostlinna Vyroba 48(8):356-360.

Nieto, K.F., and W. T. Frankenberger. 1991. Influence of adenine, isopentyl alcohol and Azotobacter chroococcum on the vegetative growth of Zea mays. Plant and Soil 135(2): 213-221.

Rodelas,B ., J. Gonzales Lopez., M.V. MartinezToledo., C.Pozo., and V. Salmeron, 1999. Influence of Rhizobium/Azotobacter and Rhizobium/Azospirilium combined inoculation on mineral composition of faba bean (Vicia faba). Biol.Fertil.Soil (29) : 165-169.

Sachin, D.N and P. Misra. 2009. Effect of Azotobacter chroococcum (PGPR) on the Growth of Bamboo (Bambusa bamboo) and Maize (Zea mays) Plants. Biofrontiers, 1(1): 24-31.

Sumadi, R. Devnita, dan B. Riznati, 2012. Pengaruh Seed coating dengan
Thiametoxam dan Bokashi terhadap pertumbuhan dan hasil benih kedele. Laporan Penelitian. Program Studi Agroteknologi. Fakultas Pertanian Unpad (Tidak dipublikasi).

Suryatmana, Pujawati, Mieke Rochimi Setiawati., I. K. Susanti, 2008. "Aplikasi Azotobacter vinelandii dan Azolla piñata untuk Bioremediasi limbah minyak bumi". Prosiding Seminar dan Kongres Nasional MKTI, Bogor).

Suryatmana, P., R Hindersah dan A. Yusuf. 2008. Pemanfaatan Molase sebagai bahan baku media produksi Azotobacter. LPP Unpad.

Syngenta. 2009. Seed Treatment. Syngenta Global. Available online at http://www. syngenta.com/en/products_brands/cruise r_page.html\# (Diakses 24 MAret 2010.

Wilde, G.,Roozeboom, K., Claassen, M., Janssen, K and Witt, M. 2004. Seed Treatment for Control of Early-Season Pests of Corn and Its Effect on Yield. J. Agric. Urban Entomol. 21(2): 75-85 